\section{Cults: divine, Pharaonic Egypt}

KATHARINA ZINN

If "cult" in general can be defined as an expression of religious ideas and values, both in ritual actions and verbal expressions, then "divine cult" is the idea that every human activity is authorized by a divine order and aimed at contact with a particular celestial power. This can itself manifest in natural phenomena or, especially in ancient Egypt, in the ongoing cycles of life: sunset to sunrise to sunset, birth to death, endlessly repeated as an act of ongoing creation (Quirke 1992: 70). This constant creation was kept alive through continuous religious ceremonies, worshipping the gods of the Egyptian pantheon, with the sun god as the most important, whose earthly representative, the king, ensured that the necessary rituals for the gods were carried out in the temples, either by himself or through his substitutes, the priests. This was seen as the fulfillment of the requirements of the divine cult.

In general, recipients of cult were gods, including deceased kings (divine cult), living kings (royal or ruler cult), and deceased private individuals (private mortuary cult). Cult in ancient Egypt involved a huge variety of rituals. There was no specific word for cult or ritual; the Egyptians referred to worshipping as "doing things" (iret ikhet). This entry will focus on the gods (netjerw) as the beneficiaries of the divine cult. Netjerw is not equivalent to the common understanding of "god" - it could be applied to people or things - but all entities called netjerw could be beneficiaries of rituals (Meeks 1988). They could be gods in the strictest sense, deified kings or other persons deified after their death, or animals that were considered manifestations of gods. The only living person who possessed the qualities of netjer was the king (Thompson 2001: 326).

The divine cult was so prominent in the minds of the Egyptians themselves (and later visitors) that the Egyptian religion is often called a cult-religion (Barta 1980: 839). The divine cult was the main state religion. The place of its practice was the temple, called the "House of the God" (Hwt netjer), which functioned as the main contact and communication point between the gods and their human partner in the dialogue, the king. The king served as a mediator: he joined in the dialogue of the gods, and was seen as a god himself during the ritual. The cult developed forms of ritual adoration and worship. Since the human site stayed the same, a hierarchy of cults and a classification of temples resulted from the relevance of the specific gods who were the recipients of worship. Size, location, architecture, and decoration of temples depended on their importance in relation to the main gods or local deities.

In each temple, several gods could be worshipped at the same time. This covered the family of the main god or goddess, the so-called triads (god - wife - child), and other inherent gods. Amun (or Amun-Re as a syncretistic merger of the Hidden One - Amun - and the sun god Re) resided with his consort MUT and their son Khonsu in Karnak (Thebes); the falcon-headed sky god, HORUs, with his parents, OSIRIS and Isis, in HIERAKONPOLIS and EDFU; the mummy-form god, PTAH, with his wife, SEKHMET, and their son, Nefertem, in Memphis. These places were some of the principal Egyptian cult sites with large major temples inhabited by important universal gods, belonging to the functional "inner" Egyptian pantheon. Their cult service was established over a long period of time.

As seen with Horus, gods could be represented in different localities, sometimes also called by different names - Horus in Hierakonpolis, but Horus-Behedetj in Edfu (Wilkinson 2000: 82). The same happened with Amun (Karnak, Luxor) and Re (Karnak, Heliopolis). The process of syncretism between Amun, Re, and MIN could strengthen the position of some gods and increase or stabilize the importance of their cult. Some deities visited each other and therefore took part in each 
other's cult practices (i.e., Hathor of Dendera and Horus-Behdetj of Edfu). The main god of a temple received the main worship, while the guest gods had their own sanctuaries and were given their own special forms of worship, both dependent on and independent from the main god. Other gods received minor, local cults. Local elites performed rituals in the local temples, as seen in AsYUT (Kahl 2007: 37). These local cults formed the basis for popular religion in their area (Becker 2007: 143), since the people saw themselves as under the protection of their town god as "the one [that the] life and death of the inhabitants depend on" (Pap. Insinger 28, 4).

We are fairly well informed about the official minor cults in Deir el-Medina, where rituals for local deities (in particular Hathor and the deified Amenhotep I) were performed in the chapels to the north of the village by lay priests who were simple workmen (McDowell 1999: 92-104). For Amenhotep I, we have an account of his daily ritual (P.Cairo 58030 and Turin CGT 54042; McDowell 1999: 93-4).

Specific cults obtained their substance from myths, transmitted in and based on specific cultural memory. Ritual cultic myth initiated the (re-)creation of the past, with the intention of it happening again and again within the cyclical time (neheh). Offerings for the different gods in the diverse temples were brought by word during the ritual and materialized in food, drink, and clothing. The goal of rituals in the divine cult was to please the addressed gods (sekhetep) and receive assistance and support from them as a gift in return. Even the priest used real food, wine, water, and clothing during the performance, and the cult was based on magic words that had to be used correctly to ensure potency (Barta 1980: 839-40).

Due to the celebration of the divine cult, temples were state institutions. The divine cult as part of the official religion was needed to maintain the cosmic order MAAT and was therefore not focused on comforting the individual with hope and forgiveness (Becker 2007:
141). The king initiated the erecting of temples as places of contact with the gods and therefore as an interface between this world and the afterlife. This was seen as his duty towards his divine father, as mentioned in the dedication texts - "he did it as his monument for his father" (Konrad 2006: 13) - and the foundation ceremony was the first step in service to the gods. Because a cyclically renewed foundation is a prerequisite for the cult (both the daily cult ritual and the festival cults), these rites were depicted on the temple walls.

From this moment on, everything happening in the temple was done on the king's behalf, including the intimate service of the gods through offering food, drink, clothing, and gifts, as well as leading the god out for processions and involvement in the accompanying rituals (Wilkinson 2000: 86). The gods, living in their cult images, were addressed by words and acts. The king was the highest priest and administrator of the land. As the representative of humanity, he was theoretically the only one able to perform the rites, as authorized communication with the gods. From the 11th Dynasty on, he was called "Lord of the Rituals" (nb iret ikhet) (Schott 1963: 103). The divine cult involved not only the god-king relationship, but also the god-king-mankind relationship. In reality, priests acted as proxies for the king, except on the very few occasions when the king fulfilled his own role. The priest, who functioned in the service of the god's image during the ritual, came from the higher class of priests, called "servants of God" (hem netjer), translated in Greek as "prophet," with the High Priest (hem netjer tepy) on top.

The primary cult practice in the temple was focused on the statue of the god (akhem, "image"), which had to be attended to. These statues were small, only about $50 \mathrm{~cm}$ tall, and made of wood, stone, or precious metal, such as the crocodile-shaped cult statue in Munich (ÄS 6080). This statue is $22 \mathrm{~cm}$ long (perhaps $30 \mathrm{~cm}$ long when its tail was still intact) and is made from copper and electrum, a natural alloy of gold and silver. After a statue 
was made, it had to undergo the ritual of the Opening of the Mouth, so that the divine $b a$, a major component of human and divine beings (often imperfectly translated as "soul"), could take up residence. The god could then be present in the cult image. It was not believed that the images were equivalent to the gods, but that they were de facto homes to accommodate the gods. The ritual prepared the cult statue for receiving the deity, which was then seen as present.

As a consequence of the cult worship, the god was called into this world, becoming immanent in the god's image (Assmann 1984: 58-9), so that his divine $b a$ could navigate the passage between this world and the other world and remain in the image (Traunecker 2001: 22, 94). The gods showed humanlike behavior and therefore had to be nursed like humans: dressed, washed, and fed (Silverman 1991: 6). Nursing the image was equivalent to caring for the god, whose life forces were regenerated by such care. The cultic veneration was bound to rituals that had existed from the earliest times of Egyptian history. This treatment provides hints towards the original meaning of the word cult from Latin colere, "to care, cultivate, till." The cult was always connected with offerings initiated by the king as "Lord of making offerings", as only he knew the created world and could search for the permanence of the ritually made objects (menw - from men, "endure, remain"; Quirke 2001: 21).

The image was placed in a shrine in the sanctuary, the darkest, innermost, hidden place in the temple, the holy of holies, where only a few people had access. This seclusion was described in a text as "more unapproachable than what happens in heaven, more arcane than the nature of the underworld" (Sethe 2010: 99, 15-16; slab stone of Thutmose I from Abydos, 18th Dynasty). The temple as a building, with its enclosure wall, pylons, courtyards, hypostyle halls, and small chambers, acted as a stage for the cult of the god. All parts were oriented towards the sanctuary: the floor rising, the ceiling lowering, resulting in increasing darkness. With each level of descent into the temple, fewer people would be granted access.

We can differentiate between the daily cult, celebrated at least every morning (in some temples also at midday and evening) and the festival cult, celebrated according to a festival calendar, which was specific to each temple. Egyptologists see a difference in the quality of these two ritualistic acts, describing the daily cult as active and functional - the ritualist is acting directly for and with the god's image while the festival cult is said to be reactive, with the paraded god experiencing the reactions and emotions of the participants "firsthand," even though the image was veiled and remained in its shrine (Assmann 1975: 58-63).

The daily cult ritual was practiced every morning before the cult image of the main god in the sanctuary. We have evidence of this from the New Kingdom, possibly even before. It was celebrated until the Greco-Roman era similarly in each temple. The reason for the seeming uniformity might be sought in its relatedness to the royal ceremony, with its clothing and dining rites. The daily cult ritual was divided into several acts, which we know from temple reliefs and papyri. None of the sources describe the whole ritual, but Pap. Berlin 3014, 3053, and 3055, describing the ritual for the Amun and Mut temples in Karnak, provide the essentials. Complemented by scenes from the Sety temple in Abydos, the whole ritual act becomes clear (Daily 2010). The best known reliefs are engraved (unluckily incomplete, due to lack of space) on the east and west walls of the sanctuary of the Horus temple in Edfu; they describe the ritual as being performed three times a daymorning, midday, and evening, with the morning ritual as the most important and the midday as the least (Watterson 1998: 80).

The daily cult consisted of the following steps (Barta 1980: 842; Braun 2010 with further literature; Watterson 1998: 81-83; Daily 2010), which guaranteed a gradual approach towards the divine (Assmann 1975: 50): 
1 entering the temple and sanctuary at dawn "when the sun's rays illuminate the earth" (E I,20,1-3), followed by the ceremonial purification of the officiant in the House of Morning, the filling of libation vessels, and the consecration of food offerings (prepared in the temple kitchens), the lighting of a torch to keep away enemies, and the recitation of texts on door jambs (a version of Declaration of innocence, Book of the dead, ch. 125 - known from many private papyri, Lichtheim 1976: 124-32);

2 opening the cult shrine by singing the Morning hymn (accompanied by priestesses and chantresses) and breaking the clay seals;

3 unveiling the cult statue, in which the god resides, the first climax as priest and god behold each other ("I saw the God, and the Powerful saw me." E I,6,4-6), resulting in the god's $b a$ entering the image, bringing the temple to life;

4 prostration and kissing the ground;

5 adoration and presentation of myrrh as a substitute for the food offerings laid out;

6 taking the statue out of the shrine, removing the cloth, ablution and anointing of the statue;

7 ritual clothing of the statue with linen (white, green, red, blue - purified by bed-natron);

8 purifying the image with water in red and green ritual vessels;

9 replacing the statue in the shrine while censing it;

10 closing the shrine;

11 walking backwards, clearing away footprints in the sanctuary by brushing the sand lying on the floor, walking around the sanctuary, extinguishing the torch, closing the door;

12 presentation of food offerings in the "Hall of Offerings" and recitation of the "Reversion of Offerings" for redistribution among the priests.

During the whole process, ritual purity was imperative and was achieved by washing the priests and implements with natron and water from the Sacred Lake before the ritual, as well as using incense during each step. The place where the ritualist prepared himself for the ritual within the temple was called the "House of the Morning" (per dwat).

In return for the affection given to the god during the rituals, it was hoped the god would help the king and all of mankind with divine power, establishing order and strengthening the power of the state. By interfering in this world, the god kept the Maat omnipresent, so that the king could reign successfully on earth (Traunecker 2001: 96).

In order to perform the rituals and have all the offerings on hand, the temples needed their temple estates ( $p e r$, a term used to describe the economic aspect of the temple complex with the subordinated word ra-per as the name of a part, provided for by the whole domain; Konrad 2006: 8-13), an unbelievably large amount of (cultivated) land, livestock, and personnel, in addition to the priest and the inner-temple servants. The major temples were thus the largest economic centers in Egypt.

SEE ALSO: Amun-Re; Cults: private (Pharaonic Egypt); Gods, Egyptian; Isis, Pharaonic Egypt; Khons (Khonsu); Kingship, Pharaonic Egypt; Memphis, Pharaonic; Oracles, Pharaonic Egypt; Priests and priestesses, Egypt; Re and Re Horakhty; Religion, Pharaonic Egypt; Ruler cult, Pharaonic Egypt; Temples, Pharaonic Egypt; Thebes, East; Thutmose I-IV.

\section{REFERENCES AND SUGGESTED READINGS}

Assmann, J. (1975) Ä̈yptische Hymnen und Gebete. Zürich.

Assmann, J. (1984) Ägypten: Theologie und Frömmigkeit einer frühen Hochkultur. Stuttgart.

Barta, W. (1980) “Kult.” In W. Helck, ed., Lexikon der Ägyptologie, vol. 3: 839-47. Wiesbaden.

Becker, M. (2007) "Popular religion in Asyut." In J. Kahl, Ancient Asyut: the first synthesis after 300 years of research. Wiesbaden.

Braun, N. (2010) Pharao und Priester - Sakrale Affirmation von Herrschaft durch Kultvollzug. 
Das tägliche Kultbildritual im Neuen Reich und der Dritten Zwischenzeit. Wiesbaden.

Daily (2010) [online] [Accessed August 29, 2010.] "Daily offering ritual in ancient Egyptian temples." Available from http://www.digital egypt.ucl.ac.uk/religion/dailycult.html.

Kahl, J. (2007) Ancient Asyut: the first synthesis after 300 years of research. Wiesbaden.

Konrad, K. (2006) Architektur und Theologie: Pharaonische Tempelterminologie unter Berücksichtigung königsideologischer Aspekte. Wiesbaden.

Lichtheim, M. (1976) Ancient Egyptian literature, vol. 2: the New Kingdom. Berkeley.

McDowell, A. (1999) Village life in Ancient Egypt: laundry lists and love songs. Oxford.

Meeks, D. (1988) “Notion de 'dieu' et structure du panthéon dans l'Egypte ancienne." Revue de l'histoire des religions 205: 425-46.

Meeks, D. and Favard-Meeks, C. (1997) Daily life of the Egyptian gods. London.

Morenz, S. (1973) Egyptian religion. London.

Quirke, S. (1992) Ancient Egyptian religion. London.

Quirke, S. (2001) The cult of Ra: sun-worship in Ancient Egypt. London.
Schott, S. (1963) "Die Opferliste als Schrift des Thot.” Zeitschrift für Ägyptische Sprache und Altertumskunde 90: 103-9.

Sethe, K. (2010) [online] [Accessed September 9, 2010] "Urkunden der 18. Dynastie. Erster Band." Available from http://digitalcase.case.edu:9000/ fedora/get/ksl:seturk01/seturk01.pdf.

Silverman, D. P. (1991) "Divinity and deities in Ancient Egypt.” In B. Shafer, ed., Religion in ancient Egypt: gods, myths, and personal practice: 7-87. Ithaca.

Teeter, E. (2001) "Cults: divine cults." In D. B. Redford, ed., The Oxford encyclopedia of Ancient Egypt, vol. 1: 340-5. Oxford.

Teeter, E. (2002) “Divine cults.” In D. B. Redford, ed., The ancient gods speak: a guide to Egyptian religion: 81-6. Oxford.

Thompson, S. E. (2001) “Cults: an overview.” In D. B. Redford, ed., The Oxford encyclopedia of Ancient Egypt, vol. 1: 326-32. Oxford.

Traunecker, C. (2001) The gods of Egypt. Ithaca.

Watterson, B (1998) The house of Horus at Edfu: ritual in an Ancient Egyptian temple. Stroud.

Wilkinson, R. H. (2000) The complete temples of Ancient Egypt. New York. 